\title{
Editorial for thematic series: XIII meeting of the Brazilian Materials Research Society, Symposium A: functional hybrid interfaces - from characterization to applications
}

\author{
Welchy Leite Cavalcanti
}

Correspondence:

welchy.leite.cavalcanti@ifam.fraunhofer.de Adhesive Bonding Technology and Surfaces, Fraunhofer Institute for Manufacturing Technology and Advanced Materials IFAM, Wiener Straße 12, D-28359 Bremen, Germany

\section{Editorial}

This special issue contains selected articles related to oral contributions presented at the XIII Meeting of the Brazilian Materials Research Society (SBPMat 2014) within the Symposium A: Functional hybrid interfaces - from characterization to applications, held in João Pessoa, Brazil, during September $28^{\text {th }}$ through October $2^{\text {nd }}, 2014$. This symposium hosted by SBPMat was organized by Welchy Leite Cavalcanti from Fraunhofer IFAM, Andréia Luísa da Rosa from Federal University of Minas Gerais (UFMG), André Avelino Pasa from Federal University of Santa Catarina (UFSC), and Silvio de Barros from Federal Center of Technological Education Celso Suckow da Fonseca (CEFET-RJ), and it was supported by the Brazilian Society of Adhesion and Adhesives (ABAA). The main focus was on design, control and characterization of hybrid polymer/solid state materials aiming at applications in optoelectronics, coatings and adhesives. Within the symposium, theoreticians and experimentalists discussed the present state of the art in the field and future trends. Diverse oral and poster contributions were presented by researchers from numerous universities, institutes and research centers. It may be highlighted that symposium A hosted various remarkable presentations by young researchers and - among them - several contributions which were at least partly supported within the program Science without Borders (Ciência sem Fronteiras) coordinated by CAPES (Coordination of Improvement of Higher Education Personnel), CNPq (National Counsel of Technological and Scientific Development) and DAAD (German Academic Exchange Service).

In order to disseminate the interdisciplinary and international work presented within Symposium A of the XIII Brazilian MRS Meeting, six contributions were selected along with the value added chain ranging from research and development towards applications of modern adhesion science. The papers were prepared and submitted to a peer review, and they result in the present Special Issue of AAS which accentuates mainly threefold strands leading to innovative adhesive joints. First physical, chemical and even biologically based processes for building functional adherents and surfaces are addressed, second the development of novel reactive polymers incorporating atmospheric carbon dioxide, and third the investigation of interactions between solid surfaces and polymers or ambient factors. Within, the addressed threefold strands, computer-supported design of reactive monomers and the arising polymers, quality

(c) 2015 Leite Cavalcanti; licensee Springer. This is an Open Access article distributed under the terms of the Creative Commons Attribution License (http://creativecommons.org/licenses/by/4.0), which permits unrestricted use, distribution, and reproduction in any medium, provided the original work is properly credited. The Creative Commons Public Domain Dedication waiver (http:// creativecommons.org/publicdomain/zero/1.0/) applies to the data made available in this article, unless otherwise stated. 
assurance during the manufacture of functional surfaces and adhesive joints, and finally the implication of effective repair solutions are illustrated.

In the first article, Scholtz et al. introduce the energy-efficient manufacture of crystalline, doped titania films using grid assisted magnetron sputtering. Moraes Lopes de Jesus et al. present strongly adhering and abrasion-resistant superhydrophilic titania/silica composite films applying a simple sol-gel route. Ureña et al. report on the adsorption properties of titania-terminated surfaces in contact with aqueous solutions of antimicrobial peptides following a bio-inspired polymer synthesis. In a fourth paper, Carrillo Beber et al. demonstrate the performance of computer-based Molecular Dynamics simulations when identifying highly active catalysts for the synthesis of cyclic carbonate monomers resulting from the fixation of carbon dioxide in epoxy rings. Brune et al. introduce an approach for Extended Non-Destructive Testing (ENDT) facilitating quality assurance already during the manufacture process of functional coatings or adhesive joints, e.g. based on carbon-fibre reinforced polymers (CFRP). Finally, Nogueira Chagas and Farias Moita display effective engineering strategies for the rehabilitation of damaged masonry structures using CFRP and glass-fibre reinforced polymers (GFRP) and a multi-layer adhesive bonding system.

The editorial and review process for this Special Issue of Applied Adhesion Science permitted to join the well-founded theoretical and experimental work of the authors to provide a widened view on present technological progress especially related to phenomena of adhesion and adhesives in biomedical areas and for environmentally compatible applications. I express my thankfulness and compliments towards the authors for their proficient and swift work, towards the reviewers for providing profound and rapid evaluations of the manuscripts, and towards the editor in chief, Silvio de Barros, for the kind and supporting cooperation.

Received: 4 March 2015 Accepted: 4 March 2015

Published online: 23 April 2015

\section{Submit your manuscript to a SpringerOpen ${ }^{\circ}$ journal and benefit from:}

- Convenient online submission

- Rigorous peer review

- Immediate publication on acceptance

- Open access: articles freely available online

- High visibility within the field

Retaining the copyright to your article

Submit your next manuscript at $\boldsymbol{\wedge}$ springeropen.com 